\title{
Остролодочники (Oxytropis DC., Fabaceae) в Алтайском заповеднике и в долине р. Чулышман
}

\section{Oxytropis DC. (Fabaceae) in the Altai Reserve and in the valley of the Chulyshman River}

\author{
Золотухин Н. И. \\ Zolotukhin N. I. \\ Центрально-Черноземный государственный природный биосферный заповедник имени профессора В. В. Алехина, Курская \\ область, Россия. E-mail: zolotukhin@zapoved-kursk.ru
}

The Central Chernozem State Nature Biosphere Reserve named after Professor V. V. Alyokhin, Kursk region, Russia

Peферат. Представлены сведения о распространении 22 видов растений из рода остролодочник (Oxytropis DC.) на территории Алтайского заповедника и в долине р. Чулышман. Сообщаются конкретные местонахождения редких видов. В Алтайском заповеднике отмечено 20 видов Oxytropis.

Ключевье слова. Алтайский заповедник, долина р. Чулышман, Oxytropis DC.

Summary. The data on the distribution of 22 species of plants from the genus Oxytropis DC. in the Altai Reserve and in the valley of the Chulyshman River are submitted. Concrete locations of the rare species are reported. In the Altai Reserve 20 species of Oxytropis are noted.

Key words. Altai Reserve, Oxytropis DC, valley of the Chulyshman River.

Алтайский государственный природный заповедник (АГЗ), организованный в 1932 г., располагается на востоке Республики Алтай в Турочакском и Улаганском районах на высотах от 434 м над ур. м. (Телецкое озеро) до 3507 м над ур. м. (г. Тошкалыкая на Шапшальском хребте), занимает 881238 га площади (по данным лесоустройств 1981-1982 и 2002-2004 гг.; по учётным кадастровым сведениям - 871206,6 га). Кроме основной территории, учитываем вкрапленные землепользования АГЗ в долине Чулышмана: кордон Аккурум, кордон Чодро, кордон Язула).

С 1998 г. территория АГЗ входит в Список всемирного культурного и природного наследия ЮНЕСКО в составе природного объекта «Алтай - Золотые Горы»; в 2009 г. Алтайскому заповеднику присвоен статус биосферного резервата. Горная лесостепь охватывает $2 \%$ площади АГЗ (17,8 тыс. га), лесной высотный пояс - 36 \%, высокогорья: субальпийский (подгольцовый), альпийский (гольцовый) и субнивальный высотные пояса вместе - 62 \% (по нашим подсчётам).

В АГЗ известно более 1600 видов сосудистых растений природной флоры. Основные гербарные фонды по территории АГЗ и окрестностей с 1991 г. хранятся в Центрально-Черноземном государственном природном биосферном заповеднике им. профессора В. В. Алехина (ЦЧЗ) - более 26400 гербарных листов, в том числе 4600 листов с долины р. Чулышман. Автор статьи проводил изучение флоры АГЗ в 1973-1991, 1993, 1995, 2000-2002, 2007-2012, 2014, 2016, 2018 гг.

Статья продолжает опубликованные работы, посвященные отдельным группам растений АГЗ: сосудистые споровые, осоки, астрагалы, деревья и кустарники (Золотухин, 1996, 2008, 2018; Сахневич, Золотухин, 2018). Структура статьи соответствует работе по обзору астрагалов АГЗ и долины р. Чулышман (Золотухин, 2018).

Приводим сведения о распространении видов рода Oxytropis на территории АГЗ и соседней не заповедной части долины р. Чулышман по высотным поясам и флористическим районам. Выделенные флористические районы в АГЗ и долине р. Чулышман: Телецкий (Т) - Прителецкая часть заповедника, 
кроме лесостепи на восточном побережье оз. Телецкого и верховий бассейна р. Кыги, лесной и высокогорные высотные пояса; Балыкчинский (Б) - лесостепь на восточном побережье оз. Телецкого, в долине р. Чулышман от устья до р. Алтынташ и в низовьях р. Чульчи, лесной и высокогорные высотные пояса в бассейнах рек Кайра, Артышту, верхней части бассейна р. Кыги; Чульчинский (Ч) - лесной и высокогорные высотные пояса в бассейне р. Чульчи, исключая бассейны её притоков Артышту и Каяккатуярыкский; Шавлинский (Ш) - лесной и высокогорные высотные пояса в бассейне р. Шавлы (Чулышманской), а также в бассейнах рек Нижний Кулаш, Средний Кулаш, Куркуре, Каяккатуярыкский и других на северном макросклоне хр. Тетыколь (Кийтыкуль) и на западном макросклоне хр. Куркуре; Узуноюкский $(У)$ - лесной и высокогорные высотные пояса в бассейнах рек Узуноюк, Тепшиоюк, а также на южном макросклоне хр. Тетыколь и северном макросклоне хр. Чулышманский; Джулукульский (Д) - высокогорья в верней части бассейна р. Чулышман с притоками Богояш, Макату, Тустуоюк и окружающими хребтами (Шапшальский, Чулышманский, Чихачева); Среднечулышманский (С) - лесостепная долина Чулышмана от р. Алтынташ до р. Нижний Кулаш с низовьями рек Шавла, Чакрым, Аксу (Чодринская); Язулинский (Я) - лесостепная долина Чулышмана от р. Нижний Кулаш до устья p. Узункарасу (Бобочек), с включением нижней части долины р. Каракем. Схема принятого нами флористического районирования АГЗ и долины Чулышмана опубликована (Золотухин, 1987, 1994, 1996). Она скопирована также в сводке по флоре Республики Алтай (Ильин, Федоткина, 2008) и в сводке по дендрофлоре АГЗ (Сахневич, Золотухин, 2018). Территории лесостепных фрагментов АГЗ в долине Чулышмана охарактеризованы ранее (Золотухин, 2016).

Рядом с условным обозначением флористических районов (Т, Б, Ш, Ч, У, Д, С, Я) приводим данные о встречаемости видов: 1 - очень редко, 2 - редко, 3 - нередко, 4 - часто. Цитируем местонахождения видов, внесённых в Красные книги Российской Федерации (2008) и Республики Алтай (2017), а также редких в заповеднике или долине Чулышмана. Принятые сокращения: басс. - бассейн, Верх. - Верхний, вост. - восточная, г. - год, гора, зап. - западная, к. - кордон, км - километры, лев. - левый, м над ур. м. - метры над уровнем моря, Ниж. - Нижний, оз. - озеро, окр. - окрестности, п. - посёлок, прав. - правый, р. - река, ур.- урочище, хр. - хребет; эксп. - экспозиция, ю-в - юго-восточная, южн. - южная; ю-з - юго-западная. Коллекторы: АГ - А. В. Галанин, АЕ - А. С. Ерофеева, ВЯ - В. А. Яковлев, ГК - Г. И. Кошелева, ГС - Г. А. Сибирякова, ИЛ - И. Б. Лебедева (Золотухина), ЛЛ - Л. Л. Ляпаива, ЛМ - Л. В. Марина, НЗ - Н. И. Золотухин, ОК - О. А. Козлова, СС - С. С. Сумачакова.

АГЗ, лесной высотный пояс. Oxytropis alpina Bunge: Т1, Б2, Ш1, Ч2, У1. O. altaica (Pall.) Pers.: T2, Б2, Ш2, Ч2, У1. O. ambigua (Pall.) DC.: Ш2, Ч1, У2. O. campanulata Vass.: Т1 (берег оз. Телецкого, 0,8 км южнее устья р. Кыги, 438 м над ур. м., в сосняке на песке, 09.08.1983, Н3; посредине между устьем р. Кыги и массивом Туолок, 436 м над ур. м, песчано-галечниковый берег, 19.08.2008, Н3; у границы АГЗ, прав. берег р. Чулышман у устья, 436 м над ур. м., на песке, 28.08.1987, Н3; у границы АГЗ, берег оз. Телецкого, мыс между заливом Карагай и устьем р. Чулышман, 436 м над ур. м., в ивняке на песке, 23.08.2002, Н3). O. songorica (Pall.) DC.: Ш1, Ч1. O. strobilacea Bunge: Ш1, Ч1, У1.

АГЗ, высокогорные высотные пояса. Oxytropis alpestris Schischk.: Д1 (граница АГЗ, хр. Чихачева, левобережье верховий р. Таскыл, 2450 м над ур. м., остепнённый склон южн. эксп., 25.06.1986, Н3; указан на картосхеме в АГЗ для южной части хр. Шапшальского - Красная книга, 2017, но в сводке по высокогорной флоре Алтая приводится только для Тувинского макросклона хр. Шапшальского Ревушкин, 1988). O. alpina Bunge: Т3, Б5, Ш5, Ч5, У5, Д4. O. altaica (Pall.) Pers.: Т5, Б5, Ш5, Ч5, У5, Д4. О. ambigua (Pall.) DC. (О. campanulata auct. non Vass.): Ш1, У2, Д1. O. argentata (Pall.) Pers.: Д3 (xp. Шапшальский, Чихачева, Макатинский горный массив, долина р. Богояш; 5 сборов в 1977, 1983 и 1986 гг.). O. deflexa (Pall.) DC.: Д1 (хр. Шапшальский, у тропы на перевал Шапшал, 2350 м над ур. м., склон южн. эксп., луг с элементами остепнения, 13.07.1983, Н3; южн. часть хр. Шапшалький, правобережье p. Верх. Чулышман, 7 км от истока, 2320 м над ур. м., луг с элементами остепнения, 14.07.1983, Н3; северный угол оз. Джулукуль, 2210 м над ур. м., лужайка среди камней, 02.07.1986, Н3). O. eriocarpa Bunge: Д3 (хр. Шапшальский, Чихачева, Макатинский горный массив; 7 сборов в 1983 и 1986 гг.). $\boldsymbol{O}$. kusnetzovii Krylov et Steinb.: Ч1 (хр. Шапшальский, левобережье оз. Итыкуль ниже протоки, р. Камени- 
стая, 1,5 км от устья, 1900 м над ур. м., на скалах вост. эксп., 07.08.1978, Н3, ИЛ), Д1? (Джулукульский «район» конкретной флоры - Ревушкин, 1981; однако позднее не показан для этого «района» - Ревушкин, 1988). O. lapponica (Wahlenb.) J. Gay: Д2 (лев. берег р. Верх. Чулышман у впадения в оз. Джулукуль, 2205 м над ур. м., субальпийский луг в ложбине, 15.07.1983, Н3; ю-в берег оз. Джулукуль, 2210 м над ур. м., терраса, суходольный луг, 15.07.1983, Н3; северный берег оз. Джулукуль, 2230 м над ур. м., лужайка среди ивняка, 02.07.1986, Н3; басс. p. Макату, прав. берег оз. Кызылдаш в верхней части, 2300 м над ур. м., терраса, субальпийский луг, 15.07.1983, Н3). O. macrosema Bunge: Д3 (хр. Чулышманский, Чихачева, долина р. Богояш; 7 сборов в 1983 и 1986 гг.). O. physocarpa Ledeb.: Д1 (хр. Шапшальский, напротив верхней трети оз. Джулукуль, 2500 м над ур. м., щебнистая осыпь южн. эксп., 30.06.1986, Н3; хр. Шапшальский, левобережье р. Верх. Чулышман в 6 км от истока, у границы с бассейном р. Каргы, 2600 м над ур. м., склон южн. эксп., щебнисто-дресвяная осыпь, 13.07.1983, Н3; р. Верх. Чулышман у водораздела с р. Каргы, 2550 м над ур. м., зарастающая щебнистая осыпь, 27.07.1987, Н3, ЛЛ; Джулукульский район конкретной флоры - Манеев, 1986; Ревушкин, 1988; окр. оз. Джулукуль - Ильин, Федоткина, 2008). O. sajanensis Jurtzev: Д3 (ю-в побережье оз. Джулукуль, 2210 м над ур. м., терраса, суходольный луг, 15.07.1983, Н3; 1 км от вост. берега оз. Джулукуль, 2220 м над ур. м., луг с элементами остепнения, 15.07.1983, Н3; правобережье р. Богояш, 30 км от устья, 2230 м над ур. м., терраса, остепнённый луг, 18.07.1983, Н3; лев. берег истока р. Богояш в 2-х км от слияния с р. Прав. Богояш, 2280 м над ур. м., травяно-кобрезиевая луготундра, 20.07.1983, Н3; прав. берег р. Богояш ниже устья р. Прав. Богояш, 2280 м над ур. м., кобрезиевник овсяницево-разнотравный, 20.06.1986, Н3; хр. Шапшальский, левобережье р. Верх. Чулышман, 6 км от истока, 2400 м над ур. м., склон ю-з эксп., луг с элементами остепнения, 13.07.1983, Н3, определение подтвердил Б. А. Юрцев в сентябре 1983 г.; хр. Шапшальский, р. Верх. Чулышман, 2350 м над ур. м., илисто-дресвяный берег озерка, 27.07.1987, Н3, ЛЛ; хр. Шапшальский, прав. берег р. Тутуоюк, напротив среднего лесочка, 2350 м над ур. м., лужайка на крутом частично каменистом склоне южн. эксп., 16.07.1990, НЗ; впервые для Алтая вид указан нами - Золотухин и др., 1986; растения имеют носик лодочки 1,2-1,8 мм и обычно однонервные прилистники, что характерно для $O$. sajanensis - Малышев, 2008; но другими признаками не отличаются от $O$. nivea Bunge; возможно, эти 2 вида следует объединять; указания $O$. nivea для хр. Шапшальского у оз. Джулукуль - Ревушкин, 1988; Ильин, Федоткина, 2008; Красная книга, 2017 - скорее всего, относятся к подобным растениям). O. setosa (Pall.) DC.: Ш1 (хр. Куркуре, между р. Алтынташ и р. Ниж. Алтынташ, субальпийский пояс, граница АГЗ, 2070 м над ур. м., на скалах южн. эксп., 07.06.1982, Н3, ГК). O. songorica (Pall.) DС.: Ч1, Д3. O. strobilacea Bunge: Б1, Ш2, Ч2, У2, Д4. O. tragacanthoides Fisch. ex DC: Д2 (прав. берег среднего истока р. Макату, 2 км выше оз. Кызылдаш, каменистый степной склон южн. эксп., 16.07.1983, Н3; граница АГЗ, водораздел между средним истоком р. Макату и нижней оконечностью оз. Чурлугхоль, 2380 м над ур. м., высокогорная степь на каменистом склоне, 16.07.1983, Н3; там же, грива между оз. Флак-Ыяш и р. Моген-Бурен, 2380 м над ур. м., 0,5 км от границы АГЗ, каменистый склон ю-з эксп., 29.06.1986, Н3; Джулукульский район конкретной флоры - Ревушкин, 1981, 1988; Манеев, 1986; окр. оз. Джулукуль - Ильин, Федоткина, 2008). O. tschujae Bunge: У2 (хр. Тетыколь, басс. p. Верх. Кулаш, граница АГЗ, вершина г. Карагыр, 2350-2397 м над ур. м., травяная тундра, 29.06.1989, Н3; басс. p. Узуноюк, хр. Шапшальский, южн. склон г. Трёхглавой, 2550 м над ур. м., терраса, щебнистая травяно-лишайниковая тундра, 06.07.1983, Н3; там же, 2650 м над ур. м., крутой каменистый склон ю-3 эксп., 06.07.1983, Н3; Д3 (южн. часть хр. Шапшальский, левобережье р. Тустуоюк, 9 км от устья, 2450 м над ур. м., склон ю-з эксп., щебнистая осыпь, 10.07.1983, Н3; южн. часть хр. Шапшальский, правобережье р. Чулышман, 2 км выше р. Тустуоюк, 2800 м над ур. м., склон южн. эксп., щебнистая осыпь, 10.07.1983, Н3; хр. Шапшальский, левобережье р. Верх. Чулышман, 4 км от истока, 2700 м над ур. м., склон ю-з эксп., травяно-дриадовая тундра, 13.07.1983, Н3; Макатинский горный массив, водораздел оз. Макату, оз. Флак-Ыяш и р. Какпек, 2420 м над ур. м., остепнённый склон южн. эксп., 26.06.1986, Н3; хр. Чихачева, басс. р. Богояш, г. Таскыл, 2920 м над ур. м., субнивальная растительность, 15.07.1977, Н3, ОК; граница АГЗ, водораздел между прав. истоком р. Башкаус и р. Прав. Богояш, 2700 м над ур. м., щебнистая тундра, 19.07.1983, Н3; верховья р. Богояш, прав. берег оз. Богояш, 2400 м над ур. м., травяно-дриадовая тундра, 15.06.1986, Н3; верховья первого прав. притока р. Богояш ниже оз. Богояш, 2700 м над ур. м., травяно-дриадово-лишайниковая тундра, 16.06.1986, Н3; граница АГЗ, между прав. прито- 
ком оз. Богояш и басс. р. Колбакая, 2600 м над ур. м., щебнистая травяно-дриадовая тундра, 18.06.1986, Н3; граница АГЗ, верховья прав. притока оз. Богояш, 2965 м над ур. м., каменистая тундра, 18.06.1986, Н3; Джулукульский район конкретной флоры - Ревушкин, 1981, 1988; Манеев, 1986). Для Джулукульского «района» конкретной флоры указан вид O. gebleri Fisch. ex Bunge (Ревушкин, 1988), но так как этот «район» охватывает не только хр. Шапшальский у оз. Джулукуль в пределах заповедника, но и верховья р. Каргы в Тыве (Ревушкин, 1981), от включения вида в состав флоры АГЗ пока воздерживаемся.

АГЗ, лесостепной высотный пояс. Oxytropis ambigua (Pall.) DC. (O. uralensis auct. non (L.) DC.): Б2, C1, Я1. O. argentata (Pall.) Pers.: Б1 (прав. борт р. Чульчи, ниже р. Артышту, 810 м над ур. м., скальные обнажения южн. эксп., 07.08.2001, Н3, AE). O. campanulata Vass.: Б1 (лев. берег р. Кайры, ниже выхода из ущелья, 480 м над ур. м., сосняк лишайниково-моховой, 09.08.2001, Н3, АЕ); С1 (прав. берег р. Чульчи у выхода из ущелья, 550 м над ур. м., тополёвый лес, 04.09.1985, Н3). O. glabra (Lam.) DC.: Б1 (по берегу Телецкого оз., близ устья р. Челюш, плоды, 07.08.1935, К. Е. Травникова Хомутова и др., 1938; прав. берег р. Чулышман, к. Аккурум, 520 м над ур. м., сыроватый луг на террасе, 12.06.1982, Н3, ГК; ур. Аккурум, 520 м над ур. м., луг в ложбине, 24.06.1988, Н3; долина Чулышмана, между к. Аккурум и ущельем р. Чульчи, 530 м над ур. м., луг в ложбине, 03.09.1985, H3. O. intermedia Bunge: Я1 (долина р. Чулышман, 1600 м над ур. м., окр. к. Язула, выше кордона, остепнённый южн. склон, 07.06.1976, ВЯ; прав. берег р. Чулышман, ниже устья р. Берехтуярык, 1650-1700 м над ур. м., степной каменистый склон южн. эксп., цветы, 24.07.1983, Н3; там же, плоды, 24.07.1983, Н3; прав. берег р. Чулышман, ур. Берехтуярык, 1600 м над ур. м., на скалах южн. эксп. над рекой, 26.06.1989, Н3; наши растения отличаются более высокими цветоносами до 12 см, опушёнными снизу листьями). $\boldsymbol{O}$. setosa (Pall.) DC.: Б2 (прав. берег р. Чулышман, 1 км выше устья р. Чульчи, 720 м над ур. м., каменисто-щебнистый склон, 23.06.1988, Н3; прав. берег р. Чулышман, 5 км выше устья р. Чульчи, р. Сондукат, 750 м над ур. м., степь на склоне южн. эксп., 21.06.1988, Н3; прав. берег р. Чулышман, прав. берег р. Алтынташ, граница АГЗ, 1500 м над ур. м., степь на каменистом склоне южн. эксп., 08.06.1982, Н3, ГК; там же, прав. берег р. Алтынташ, 1650 м над ур. м., степной каменистый склон,17.06.1988, Н3; там же, 1750 м над ур. м., степной каменистый склон,16.06.1988, Н3). O. songorica (Pall.) DC.: Б2, С2. O. strobilacea Bunge: Б2, С2, Я2.

Долина р. Чулышман (вне современной территории АГЗ), лесостепной высотный пояс. Oxytropis ambigua (Pall.) DC. (O. uralensis auct. non (L.) DC., pp. ): Б1, С1, Я1. O. argentata (Pall.) Pers.: Б2, С2. O. campanulata Vass.: (O. uralensis auct. non (L.) DC., pp.): Б2, C2. O. deflexa (Pall.) DC.: Б1 (берег Телецкого оз. у залива Кырсай - Крылов, 1933; Ильин, Федоткина, 2008); Я1 (прав. берег р. Чулышман, 2 км ниже п. Язула, 1530 м над ур. м., берег ручья, лужайка на каменистом склоне, 25.07.1983, Н3; прав. берег р. Чулышман, ниже устья р. Верх. Кулаш, 1600 м над ур. м., песчаный берег, кустарниковые заросли, 15.08.1979, Н3, ИЛ, ГС; прав. берег р. Верх. Кулаш, 1 км от устья, 1650 м над ур. м., остепнённый луг в лиственнично-еловом лесу, 15.08.1979, Н3, ИЛ, ГС). O. glabra (Lam.) DC.: Б3 (9 гербарных сборов; самый ранний: низовья р. Чулышман, прав. берег, 460 м над ур. м., остепнённый луг в 2-х км от впадения р. Кайру в р. Чулышман, 20.07.1958, И. А. Коротков; самый поздний: долина р. Чулышман, ур. Чергей, 480 м над ур. м., остров, поляна в тополёво-берёзовом лесу на песке, 09.08.2001, Н3), С1 (долина р. Чулышман, лев. берег, ур. Катуярык, 650 м над ур. м., злаково-разнотравный топольник, 29.07.1983, Н3). O. intermedia Bunge: С1 (долина p. Чулышман, лев. берег, 2 км ниже р. Тайбулку, 700 м над ур. м., каменистая терраса с лишайниками и редкими цветковыми, 23.05.1982, Н3, ГК; долина р. Чулышман, прав. берег, ниже Чодро, у брода Ару, 750 м над ур. м., песчано-галечниковый берег, 24.05.1982, Н3; ГК), Я2 (прав. берег р. Чулышман, 2 км ниже р. Средний Кулаш, 1400 м над ур. м., степной каменистый склон южн. эксп., 25.07.1983, Н3; долина р.Чулышман, прав. берег, спуск тропы в басс. p. Средний Кулаш, 1350 м над ур. м., степь на склоне, 10.08.1988, С. В. Спицын; долина р. Чулышман, окр. к. Язула, между ур. Каратумыс и Таштумес, 1670 м над ур. м., остепнённый склон южн. эксп. среди леса, 07.06.1976, ВЯ; прав. берег р. Чулышман, 3 км выше к. Язула, 1720 м над ур. м., степь на склоне южн. эксп., 24.07.1983, Н3; долина р. Чулышман, прав. берег р. Верх. Кулаш, 0,5 км от устья, 1640 м над ур. м., обнажение у реки, 15.08.1979, Н3, ИЛ, ГС; наши растения отличаются более высоки- 
ми цветоносами до 13 см, опушёнными снизу листьями; около ур. Язула - Крылов, 1933; близ п. Язула, южн. каменистый склон к р. Чулышман, $58^{\circ} 26^{\prime}$ в.д. $50^{\circ} 37^{\prime}$ с.ш., 11.07 .1935 , М. С. Хомутова - Хомутова и др., 1938). O. pilosa (L.) DC.: Б1 (долина р. Чулышман, близ Кумуртука - Крылов, 1933; в низовьях р. Чулышман, вблизи устья её притока р. Башкаус - Ильин, Федоткина, 2008); С1 (лев. берег р. Чулышман, напротив устья р. Шавлы, 940 м над ур. м., терраса, стоянка, залежь, 24.08.1979, Н3). O. recognita Bunge: C1 (долина p. Чулышман, p. Шавла, 1 км от устья, 940 м над ур. м., остров, песчано-галечниковый берег, 25.07.1983, Н3; р. Шавла, 2 км от устья, 950 м над ур. м., остров, галечниково-песчаный берег, 03.07.1989, Н3). O. setosa (Pall.) DC.: Б3, С3. O. tragacanthoides Fisch. ex DC.: С2 (долина р. Чулышман от 3-х км ниже р. Итукая (Утукая) до брода Ару; 5 сборов в 1976, 1977, 1982 гг.). O. songorica (Pall.) DC.: Б2, C2. O. strobilacea Bunge: Б3, С2, Я2.

Высотные пределы видов (нижний и верхний, в метрах над уровнем моря) в Алтайском заповеднике и долине р. Чулышман; листов гербария в ЦЧЗ - с территории АГЗ / с долины р. Чулышман вне современной территории АГЗ. Oxytropis alpestris: 2450; 1/0. O. alpina: 1550-2950; 50/0. O. altaica: $1500-2900 ; 30 / 0$. O. ambigua: 440-2250; 16/2. O. argentata: 550-2600; 6/5. O. campanulata: 436-700; 6/6. O. deflexa: 440-2350; 3/3. O. eriocarpa: 2300-2650; 7/0. O. glabra: 450-650; 3/10. O. intermedia: 700-1750; 4/7. O. kusnetzovii: 1900; 1/0. O. lapponica: 2200-2350; 4/0. O. macrosema: 2300-2500; 7/0. O. physocarpa: 2450-2650; 3/0. O. pilosa: 470-940; 0/1. O. recognita: 940-950;0/2. O. sajanensis: 2200-2400; 8/0. O. setosa: 500-2100; 6/5. O. songorica: 460-2300; 16/2. O. strobilacea: 450-2700; 38/17. O. tragacanthoides: 650-2450;3/5. O. tschujae: 2350-2965; 13/0.

Для территории Республики Алтай приводится более 40 видов рода Oxytropis (Крылов, 1933; Положий, 1994; Ильин, Федоткина, 2008; Малышев, 2008; Пяк, 2012). Многие из этих видов являются эндемиками и субэндемиками Центрального и Юго-Восточного Алтая в бассейне р. Катуни. Разнообразие Oxytropis Восточного Алтая (бассейн оз. Телецкого) существенно меньше. В приведённом выше перечне остролодочников АГЗ и долины р.Чулышман 22 вида. Среди них 3 вида (Oxytropis alpestris, O. physocarpa, O. tschujae) внесены в Красную книгу Российской Федерации (2008), а 1 вид (Oxytropis alpestris) - в Красную книгу Республики Алтай (2017). Для современной территории АГЗ в представленном выше перечне указано 20 видов Oxytropis. У некоторых видов уточнены приводимые ранее (3олотухин и др., 1986; Ильин, Федоткина, 2008) высотные пределы их распространения в Горном Алтае.

\section{ЛИТЕРАТУРА}

Золотухин Н. И. Опыт флористических исследований на уровне фитохорий наименьшего ранга (на примере Алтайского заповедника) // Теоретические и методические проблемы сравнительной флористики: Материалы II рабочего совещ. по сравнительной флористике. - Л.: Наука, 1987. - С. 90-104.

Золотухин Н. И. Анализ флоры высокогорий Алтайского заповедника // Актуальные проблемы сравнительного изучения флор: Материалы III рабочего совещ. по сравнительной флористике. - СПб.: Наука, 1994. - С. 321 331.

Золотухин Н. И. Изучение разнообразия сосудистых растений в заповедниках: Методическое пособие и краткий обзор. - М.: KMK Scientific Press Ltd., 1996. - 60 c.

Золотухин Н. И. Осоки (Carex L., Суреraceae) Алтайского заповедника и сопредельных территорий // Биоразнообразие, проблемы экологии Горного Алтая и сопредельных регионов: настоящее, прошлое, будущее. Материалы Междунар. конф. (22-26 сентября 2008, г. Горно-Алтайск). Часть І. - Горно-Алтайск: РИО ГАГУ, 2008. - С. 230-236.

Золотухин Н. И. Растения из Красной книги России в лесостепной долине реки Чулышман (Восточный Алтай) по материалам Алтайского и Центрально-Черноземного заповедников // Проблемы ботаники Южной Сибири и Монголии: Сб. науч. ст. по материалам XV междунар. науч.-практ. конф. (23-26 мая 2016 г., Барнаул). - Барнаул: Концепт, 2016. - С. 236-242.

Золотухин Н. И. Астрагалы (Astragalus L., Fabaceae) в Алтайском заповеднике и долине реки Чулышман // Проблемы ботаники Южной Сибири и Монголии: сб. науч. статей по материалам XVII междунар. науч.-практ. конф. (24-27 мая 2018 г., Барнаул). - Барнаул: Изд-во АлтГУ, 2018. - С. 71-74. 
Золотухин Н. И., Золотухина И. Б., Марина Л. В. Флора высокогорий Алтайского заповедника // Новое о флоре Сибири. - Новосибирск: Наука, 1986. - С. 190-209.

Ильин В. В., Федоткина Н. В. Сосудистые растения Республики Алтай: аннотированный конспект флоры. Горно-Алтайск: РИО ГАГУ, 2008. - 291 с.

Красная книга Республики Алтай (растения). 3-е изд. перераб. и доп. / Отв. ред.: А. Г. Манеев. - Горно-Алтайск, 2017. - 267 с.

Красная книга Российской Федерации (растения и грибы) / Сост.: Р. В. Камелин и др. - М.: Товарищество научных изданий КМК, 2008. - 855 с.

Крылов П. Н. Oxytropis DC. Остролодочник // Флора Западной Сибири. Вып. 7: Rosaceae - Papilionaceae. Томск, 1933. - С. 1713-1766.

Малышев Л. И. Разнообразие рода Остролодка (Oxytropis) в Азиатской России // Turczaninowia, 2008. - Т. 11, вып. 3. - С. 5-141.

Манеев А. Г. Конспект флоры хребта Чихачева // Новое о флоре Сибири. - Новосибирск: Наука, 1986. - С. $87-137$.

Положий A. В. Oxytropis DC. - Остролодочник // Флора Сибири. Т. 9: Fabaceae (Leguminosae). - Новосибирск: Наука, 1994. - С. 74-151.

Пяк А. И. Бобовые - Fabaceae (Leguminosae) // Определитель растений Республики Алтай / Отв. ред. И. М. Красноборов, И. А. Артемов. - Новосибирск: Изд-во СО РАН, 2012. - С. 267-297.

Ревушкин A. C. Конспект высокогорной флоры Шапшальского хребта // Новые данные о фитогеографии Сибири. - Новосибирск: Наука, 1981. - С. 140-170.

Ревушкин A. С. Высокогорная флора Алтая. - Томск: Изд-во Том. ун-та, 1988. - 320 с.

Сахневич М. Б., Золотухин Н. И. Аннотированный список дендрофлоры Алтайского заповедника. - Горно-Алтайск: ФГБУ АГПБЗ, 2018. - 62 с.

Хомутова М. С., Золотовский М. В., Гончарова А. Н. Список растений Алтайского государственного заповедника // Тр. Алтайск. гос. заповедника. Вып. 2. - М., 1938. - С. 139-247. 